\title{
Interactions of tillage and soil depth on fluometuron degradation in a Dundee silt loam soil
}

\author{
R.M. Zablotowicz ${ }^{*}$, M.A. Locke, L.A. Gaston ${ }^{1}$, C.T. Bryson \\ USDA-ARS, Southern Weed Science Research Unit, PO Box 350, Stoneville, MS 38776, USA
}

Received 20 December 1999; received in revised form 3 July 2000; accepted 13 July 2000

\begin{abstract}
Fluometuron ( $N, N$-dimethyl- $N^{\prime}$-[3-(trifluoromethyl)phenyl]urea) is the most widely used soil applied herbicide in cotton (Gossypium hirsutum) production in the Southeastern United States. Thus, there is a need to understand the persistence of this herbicide under various crop management systems in regards to both herbicide efficiency and environmental fate. The effects of long-term no-tillage practices on fluometuron degradation were studied in a Dundee silt loam under laboratory conditions. Soil was collected at four depths (0-2, 2-5, 5-10, and 10-25 cm) from field plots following 11 years of continuous no-tillage (NT) or conventional tillage (CT). Organic carbon content, microbial biomass, and fluorescein diacetate (FDA)-hydrolytic activity were 48,106 , and $127 \%$ greater, respectively, in the upper $2 \mathrm{~cm}$ of NT soil compared to CT soil. Microbial biomass and FDA-hydrolytic activity were 39-66 and 34-99\% greater in the CT compared to NT soil, respectively, in the 2-5 and 5$10 \mathrm{~cm}$ depths. Fluometuron degradation was assessed under laboratory conditions using ${ }^{14} \mathrm{C}$-ring labeled fluometuron. Fluometuron was degraded more rapidly at depths between 0 and $10 \mathrm{~cm}$ of the CT soil relative to the NT soil. Fluometuron degradation was described as first-order $(k=0.0754,0.0608,0.0273$, and 0.0074 per day in the $0-2,2-5,5-10$, and 10-25 $\mathrm{cm}$ depths of CT soils compared to $0.035,0.0368,0.0145$, and 0.0138 per day in respective depths of NT soil). Although the surface $0-2 \mathrm{~cm}$ of the NT soil had greater microbial activity and biomass, higher fluometuron sorption in the surface $0-2 \mathrm{~cm}$ NT soil compared to $\mathrm{CT}$ (Freundlich coefficient $\left[K_{\mathrm{f}}\right] \mathrm{NT}=7.12$ versus $\mathrm{CT}=1.88$ ) reduced fluometuron solution concentration in NT soil and may have impeded degradation. Interactions between soil biological activity and fluometuron soil solution concentrations, mediated by sorption, may determine the potential for fluometuron degradation in soils under long-term NT practices. Published by Elsevier Science B.V.
\end{abstract}

Keywords: No-tillage; Microbial degradation; Herbicide sorption; Microbial biomass; Microbial activity

\section{Introduction}

The implementation of reduced tillage practices influences the patterns of organic matter accumulation

\footnotetext{
* Corresponding author. Tel.: +1-662-686-5260; fax: +1-662-686-5422.

E-mail address: rzablotowicz@ars.usda.gov (R.M. Zablotowicz).

${ }^{1}$ Present address: Department of Agronomy, Louisiana State University, Baton Rouge, LA, USA.
}

in soil and subsequent biological, chemical and physical soil properties. Typically, total organic carbon in the surface soil increases as the degree of tillage is reduced and subsequently elevated microbial activities and populations are observed (Doran, 1980; Linn and Doran, 1984; Levanon et al., 1994; Reddy et al., 1995; Wagner et al., 1995). The adoption of conservation management practices such as no-tillage (NT) may affect the fate of herbicides through interactions with factors mediated by soil organic matter, namely, 
microbial degradation and sorption of the herbicide and its metabolites (Locke and Bryson, 1997).

A major effect of reduced tillage is the increased sorption of herbicides under NT systems. Most herbicides, e.g., acifluorfen \{5-chloro-4-(trifluoromethyl)phenoxy]-2-nitrobenzoic acid\} (Locke et al., 1997), alachlor [2-chloro- $N$-2,6-diethylphenyl)- $N$-methoxymethyl)acetamide] (Locke, 1992), chlorimuron \{ethyl-2-[[[[(4-chloro-6-methoxy-2-pyrimidinyl)amino]carbonyl]amino]sulfonyl]benzoate $\}$ (Reddy et al., 1995), \{cyanazine 2-[[4-chloro-6-(ethylamino)-1,3, 5-tiazin-2-yl]amino]-2-methylpropanenitrile\}(Reddy et al., 1997), fluometuron (Brown et al., 1994; Locke et al., 1995) have a high binding affinity for organic matter that accumulates in surface soil under NT conditions. However, differential effects of tillage management on herbicide degradation have been reported (Locke and Bryson, 1997). The specific effects of reduced or NT management on the fate of a particular herbicide depends upon several factors: the chemical nature of the herbicide, the nature and history of the tillage regime, history of exposure to the herbicide, and specific soil parameters, e.g., organic matter content, $\mathrm{pH}$, soil texture, and clay mineralogy. Research from our laboratory has demonstrated similar persistence of alachlor, chlorimuron and metribuzin [4-amino-6-(1,1-dimethylethyl)-3-(methylthio)-1,2,4triazin-5(4(H)-one] in NT and CT soils, however, tillage, influenced the mineralization, incorporation into unextractable residues and accumulation of metabolites from these herbicides (Locke et al., 1996; Reddy et al., 1995; Locke and Harper, 1991). Bentazon [3-(1-methylethyl)-(1H)-2,1,3-benzothiadiazin4(3H)-one 2,2-dioxide] degradation was more rapid in certain NT soils compared to CT soils (Wagner et al., 1996) and was influenced by several factors including history of exposure, soil $\mathrm{pH}$, and duration of NT management. Higher mineralization of the herbicide atrazine [6-chloro- $N$-ethyl- $N$ '-(1-methylethyl)-1,3,5-triazine-2,4-diamine] and the insecticides diazinon and carbofuran was observed in NT compared to CT soils (Levanon et al., 1994) and was associated with higher microbial populations and activities.

Fluometuron is a widely used herbicide for cotton production, especially in the southeastern US, and is applied at $1.2-2.2 \mathrm{~kg} \mathrm{ha}^{-1}$ pre-plant incorporated, pre-emergence or post-emergence for control of a variety of broadleaf and grassy weeds. Concentrations of fluometuron (up to $20 \mu \mathrm{g}^{-1}$ ) and its major metabolite, desmethyl fluometuron (up to $5 \mu \mathrm{g}^{-1}$ ) have been detected in Mississippi Delta surface waters (Zablotowicz et al., 2000). Mueller et al. (1992) showed that fluometuron was more readily degraded in the surface of a Mississippi Delta soil (Beulah silt loam) with decreasing degradation rates at lower soil depths that correlated with reduced microbial biomass. The interactions of a hairy vetch cover crop and tillage on fluometuron degradation were assessed by Brown et al. (1994, 1996). In a laboratory study, fluometuron degradation was more rapid in surface $(0-4 \mathrm{~cm})$ CT soil without the cover crop than in NT soil planted to a winter cover crop of hairy vetch (Brown et al., 1994). This was attributed to higher fluometuron sorption in NT vetch cover cropped soils. However, under field conditions initial fluometuron degradation rates were not affected by tillage or cover crop (Brown et al., 1996). Laboratory studies by Locke et al. (1995) observed similar degradation of fluometuron in the surface $(0-2 \mathrm{~cm})$ of Dundee silt loam soil collected from plots under CT and NT for 4 years. However, these studies showed that surface $(0-2 \mathrm{~cm})$ soils from CT and NT plots with a herbicide-desiccated ryegrass cover crop had more rapid fluometuron degradation than soil from corresponding plots without ryegrass. Other studies showed that amending a NT Dundee soil with ryegrass residues increased the potential for fluometuron degradation to a greater extent than soil collected from NT ryegrass cover crop plot (Zablotowicz et al., 1998).

The current studies were designed to critically assess the implications of long-term NT of a typical Mississippi Delta soil on soil microbial activity, fluometuron degradation, and sorption. The degradation and sorption components of this project are laboratory-based studies that were conducted to aide in the interpretation of ongoing field studies assessing fluometuron fate under conservation tillage (Locke et al., 1999). Laboratory incubation studies utilizing radiolabeled herbicide enables the determination of a mass balance and complete pathway of dissipation, however, these results may not always correspond to results under field conditions where leaching and fluctuations in moisture and temperature may effect herbicide degradation and movement. 


\section{Materials and methods}

\subsection{Soils and soil characterization}

The Dundee silt loam (fine-silty, mixed thermic, Aeric Ochraqualf) soil used in this study was collected from a long-term tillage field experiment near Stoneville, Mississippi. The soil was collected at random from within five replications of conventional tillage (CT) plots or long-term (11 years) NT plots. In the NT plots, no mechanical tillage practices were used on these plots since establishment of the research plots. The tillage practices used in the CT plots, would be considered reduced tillage for this geographical region, and consisted of cultivation with a disc harrow in the spring to a depth of $15-20 \mathrm{~cm}$ (4-6 weeks prior to planting). A field cultivator was also used in CT plots before planting to smooth soil surface. Soil was collected at four depths: $0-2,2-5,5-10$, and $10-$ $25 \mathrm{~cm}$. The soils had no history of fluometuron application, and all plots received applications of glyphosate [N-(phosphonomethyl)glycine] followed by paraquat $\left(1,1^{\prime}\right.$-dimethyl-4,4'-bipyridium ion) both $1.1 \mathrm{~kg}$ active ingrediant ha $\mathrm{h}^{-1}$ prior to soybean planting to kill spring vegetation. The soil was sampled before planting in the spring 4 weeks after glyphosate application and 3 weeks after the CT soils were disked. Soils from each plot were passed through $2 \mathrm{~mm}$ sieve and soil moisture was determined. Organic carbon was determined by dichromate digestion (Nelson and Sommers, 1982). Fluorescein diacetate hydrolysis was used as a general indicator of soil microbial activity (Schnürer and Roswall, 1982). Soil microbial biomass was determined by chloroform fumigation and determination of ninhydrin reactive compounds (Jorgenson and Brooks, 1990) corrected for ninhydrin reactive components in non-fumigated soil. Soil for degradation and sorption studies was a composite prepared by mixing equal oven dry weight equivalents from all five replicates collected from field plots for each tillage and soil depth.

\subsection{Fluometuron degradation}

Fluometuron degradation was studied using soil treatment, extraction and analytical techniques described elsewhere (Zablotowicz et al., 1998; Locke et al., 1995). In preliminary studies, mineralization of fluometuron (complete degradation to $\mathrm{CO}_{2}$ ) in surface CT or NT soil was less than $3 \%$ over 25 days incubation, thus was not measured. Briefly, field moist soil (5.0 $\mathrm{g}$ air-dried equivalent of the composite sample) was placed in centrifuge tubes $(25 \mathrm{ml}$, corex with Teflon-lined screw cap, 15 tubes for each tillage regime and soil depth). A solution containing a mixture of non-labeled and ${ }^{14} \mathrm{C}$-ring labeled fluometuron was added to attain $9.7 \mu \mathrm{mol} \mathrm{kg}^{-1}$ soil and $840 \mathrm{MBq} \mathrm{kg}^{-1}$ soil and a moisture content of $300 \mathrm{~g} \mathrm{~kg}^{-1}$ soil. Three replicate tubes for each depth and treatment were sampled after incubating for 0,4 , 11,17 and 25 days at $28^{\circ} \mathrm{C}$. Fluometuron and metabolites were extracted from soil with four sequential $15 \mathrm{ml}$ methanol extractions with the initial extraction shaken $24 \mathrm{~h}$ and the three others for $2 \mathrm{~h}$. Radioactivity recovered from each extraction was determined by liquid scintillation counting (Packard TriCarb 4000 Series, Packard Instruments, Meriden, CT) using Ecolume cocktail (ICN, Costa Mesa, CA). The first two extracts were combined and reduced to $2 \mathrm{ml}$ under $\mathrm{N}_{2}$ gas. Analysis of fluometuron and metabolites was by radiological thin layer chromatography (RAD-TLC) analyzed by linear image scanning (Bioscan 200 linear scanner, Bioscan, Washington, DC) using chloroform:ethanol $(95: 5(\mathrm{v} / \mathrm{v}))$ as solvent and silica gel TLC plates as described elsewhere (Locke et al., 1995; Wagner and Zablotowicz, 1997; Zablotowicz et al., 1998). Residual radioactivity in extracted soil was determined by oxidation (Packard 306 oxidizer, Packard Instrument, Meridian, CT) and liquid scintillation counting.

\subsection{Fluometuron sorption}

Adsorption of fluometuron was determined using a batch equilibration technique (Locke, 1992; Reddy et al., 1995). Briefly, $5 \mathrm{~g}$ of air-dried soil was placed in $25 \mathrm{ml}$ corex centrifuge tubes with Teflon-lined screw caps. Ten milliliters of radio-labeled fluometuron solution was added to each tube and sealed with a Teflon-lined cap. Fluometuron concentrations were $0.1,1,4$ and $8 \mu \mathrm{mol} \mathrm{kg}^{-1}$ soil with a total radioactivity of about $200 \mathrm{MBq} \mathrm{kg}^{-1}$ soil. Treatments without soil were included (to determine initial radioactivity) and each concentration was replicated five times. Samples were incubated at room temperature on a rotary shaker for $24 \mathrm{~h}$. After shaking, the tubes were centrifuged 
$(10 \mathrm{~min}$ at $5900 \mathrm{~g})$ and the supernatant removed. Radioactivity remaining in solution was determined from two $1 \mathrm{ml}$ aliquots of the supernatant using liquid scintillation counting with Ecolume scintillation cocktail.

\subsection{Data analysis}

In sorption studies, the equilibria between herbicide sorbed and in solution were determined by the Freundlich equation

$S=K_{\mathrm{f}} C^{N}$

where $S$ is the amount of herbicide sorbed $\left(\mu \mathrm{mol} \mathrm{kg}{ }^{-1}\right), C$ the solution concentration $\left(\mu \mathrm{mol} \mathrm{l}^{-1}\right)$, and $K_{\mathrm{f}}$ and $N$ are empirical constants where $K_{\mathrm{f}}$ is the Freundlich coefficient $\left(\mathrm{Kg}^{-1}\right)$ and $N$ a dimensionless parameter.

First-order kinetics were used to describe fluometuron degradation when (1) partitioning of fluometuron between solution and sorbed phases was ignored and degradation was assumed to occur at an equal rate in both phases, and (2) partitioning was included and degradation assumed to occur only in solution. Fluometuron degradation was determined by fitting, in the first case,

$\frac{\mathrm{d} M}{\mathrm{~d} t}=-k_{1} M$

where $M$ is the total mass of fluometuron and $k_{1}$ the degradation rate constant (per day).

The second case is biologically more reasonable. It describes the change in total mass of fluometuron as due to degradation in solution. Total mass of fluometuron was written in terms of solution and sorbed concentrations, such as in Eq. (3):

$M=v C+m S$

where $C$ is the solution concentration of fluometuron $(\mu \mathrm{M}), S$ the sorbed concentration $\left(\mu \mathrm{mol} \mathrm{kg}{ }^{-1}\right), v$ the soil solution volume $\left(1^{3}\right)$ and $m$ the soil mass $(\mathrm{kg})$. The change in total fluometuron was set equal to degradation in solution by Eq. (4):

$\frac{\mathrm{d} M}{\mathrm{~d} t}=-v k_{2} C$

where $k_{2}$ (per day) is the rate constant for degradation in solution. From Eq. (3)

$v \frac{\mathrm{d} C}{\mathrm{~d} t}+m \frac{\mathrm{d} S}{\mathrm{~d} t}=-v k_{2} C$

and since $S=K_{\mathrm{f}} C^{N}$

$\left[v+m K_{\mathrm{f}} N C^{(N-1)}\right] \frac{\mathrm{d} C}{\mathrm{~d} t}=-v k_{2} C$

This equation was expressed in finite difference form (van Genuchten, 1981), solved and a leastsquares procedure was used to optimize $k_{2}$ when predicted $(M=v C+m S)$ values of total extractable fluometuron from Eq. (4) were fit to measured values.

\section{Results and discussion}

\subsection{Soil characterization}

The highest organic carbon content was observed in the $0-2 \mathrm{~cm}$ depth of NT soil and was about $50 \%$ greater than for the same depth of CT soil (Table 1).

Table 1

Organic carbon content, microbial biomass and FDA-hydrolytic activity of a Dundee silt loam as affected by tillage and depth ${ }^{\mathrm{a}}$

\begin{tabular}{|c|c|c|c|c|c|c|}
\hline \multirow[t]{2}{*}{ Depth $(\mathrm{cm})$} & \multicolumn{2}{|c|}{ Organic carbon $\left(\mathrm{g} \mathrm{kg}^{-1}\right)$} & \multicolumn{2}{|c|}{ Microbial biomass $\left(\mathrm{mg} \mathrm{N} \mathrm{kg}^{-1}\right)$} & \multicolumn{2}{|c|}{ FDA hydrolysis $\left(\mathrm{nmol} \mathrm{g}^{-1} \mathrm{~h}^{-1}\right)$} \\
\hline & NT & $\mathrm{CT}$ & NT & $\mathrm{CT}$ & NT & $\mathrm{CT}$ \\
\hline $0-2$ & $30.1 \mathrm{a}$ & $20.3 \mathrm{~b}$ & $175 \mathrm{a}$ & $85 \mathrm{~b}$ & $1753 \mathrm{a}$ & $772 \mathrm{~b}$ \\
\hline $2-5$ & $11.8 \mathrm{a}$ & $11.2 \mathrm{a}$ & $84 \mathrm{~b}$ & $117 \mathrm{a}$ & $561 \mathrm{~b}$ & $750 \mathrm{a}$ \\
\hline $5-10$ & $5.9 \mathrm{a}$ & $6.9 \mathrm{a}$ & $21 \mathrm{~b}$ & $35 \mathrm{a}$ & $249 \mathrm{~b}$ & $496 \mathrm{a}$ \\
\hline $10-25$ & $3.3 \mathrm{a}$ & $4.4 \mathrm{a}$ & $<10$ & $<10$ & $91 \mathrm{a}$ & 83 a \\
\hline
\end{tabular}

\footnotetext{
${ }^{a}$ Means within a depth for organic carbon, microbial biomass and FDA hydrolysis followed by the same letter are not significantly
} different at the $5 \%$ level of probability. 
Organic carbon content decreased with depth and was not significantly different among tillage treatments from 2 to $25 \mathrm{~cm}$. The highest level of microbial biomass was also observed in the $0-2 \mathrm{~cm}$ depth of the NT soil and was also about twice the biomass of CT soil (Table 1). In the $2-10 \mathrm{~cm}$ soil depths, microbial biomass was significantly greater in $\mathrm{CT}$ compared to NT soil. At the $10-25 \mathrm{~cm}$ depth, ninhydrin reactive materials extracted from non-fumigated soil approached similar levels of the fumigated soil indicating low biomass. FDA-hydrolytic activity exhibited a similar pattern as microbial biomass in relation to tillage and soil depth. Accumulation of organic matter under NT maintained high microbial biomass and activity in the surface soil. Likewise, limited introduction of labile organic matter at lower depths restricted microbial biomass development and subsequent microbial/enzyme activity in the lower depths $(2-10 \mathrm{~cm})$ of NT soils.

\subsection{Fluometuron degradation}

Fluometuron was degraded via $\mathrm{N}$-dealkylation (formation of desmethyl fluometuron and trifluoromethylphenylurea [TFMPU]) and incorporation of the ring moiety into unextractable humic components (Tables 2 and 3). Initial recovery of fluometuron by methanol extraction exceeded $98 \%$ in all samples at day 0 (data not shown). With increasing incubation time a greater amount of radioactivity was incorporated into unextractable soil components. TFMPU was only observed in the surface $0-2$ and $2-5 \mathrm{~cm}$ depths, and in most cases, only in CT soils (Table 2). In the soil samples from the upper $10 \mathrm{~cm}$ depths, fluometuron was degraded more rapidly in CT compared to NT soil, while fluometuron degradation was slightly more rapid in NT soils at the $10-25 \mathrm{~cm}$ depth. In NT soils collected from the $0-2 \mathrm{~cm}$ depth, fluometuron degradation was relatively rapid until the initial $40 \%$ of fluometuron was degraded (11 days). Degradation proceeded much slower after this point, suggesting that fluometuron degradation in NT surface soil was eventually limited by restricted bioavailability. More rapid fluometuron degradation in the $2-10 \mathrm{~cm}$ soil depths of CT compared to NT soils corresponds with higher microbial activity (FDA-hydrolytic activity). Estimates of microbial biomass in CT soils compared to these same depths in NT soils follows the same trend with regard to fluometuron degradation. Even though there was no history of fluometuron application in this soil, the rate of degradation observed in the CT soils was similar to that of a Dundee silt loam soil with a history of fluometuron exposure (Locke et al., 1995).

Table 2

Recovery of ${ }^{14} \mathrm{C}$ label in fluometuron and metabolites from the upper $0-2$ and $2-5 \mathrm{~cm}$ of a Dundee silt loam as affected by tillage during 25 days incubation ${ }^{\mathrm{a}}$

\begin{tabular}{|c|c|c|c|c|c|c|c|c|c|c|}
\hline \multirow[t]{3}{*}{ Day } & \multicolumn{10}{|c|}{$\%$ initial ${ }^{14} \mathrm{C}$ fluometuron recovered as } \\
\hline & \multicolumn{2}{|c|}{ Fluometuron } & \multicolumn{2}{|c|}{$\begin{array}{l}\text { Desmethyl } \\
\text { fluometuron }\end{array}$} & \multicolumn{2}{|c|}{$\begin{array}{l}\text { Trifluoromethyl } \\
\text { phenylurea }\end{array}$} & \multicolumn{2}{|c|}{ Non-extractable } & \multicolumn{2}{|c|}{ Total recovery } \\
\hline & $\mathrm{CT}$ & NT & $\mathrm{CT}$ & NT & $\mathrm{CT}$ & NT & $\mathrm{CT}$ & NT & $\mathrm{CT}$ & NT \\
\hline \multicolumn{11}{|c|}{ Depth $(0-2 \mathrm{~cm})$} \\
\hline 4 & $93.3 \mathrm{a}$ & $90.7 \mathrm{a}$ & $1.1 \mathrm{a}$ & $1.8 \mathrm{a}$ & ND & ND & $4.6 \mathrm{a}$ & $5.9 \mathrm{a}$ & $99.0 \mathrm{a}$ & $98.4 \mathrm{a}$ \\
\hline 11 & $51.5 \mathrm{~b}$ & $66.3 \mathrm{a}$ & $30.8 \mathrm{a}$ & $19.2 \mathrm{~b}$ & 1.1 & ND & $12.7 \mathrm{a}$ & $13.3 \mathrm{a}$ & $96.1 \mathrm{a}$ & $98.9 \mathrm{a}$ \\
\hline 17 & $13.3 \mathrm{~b}$ & $51.2 \mathrm{a}$ & $45.8 \mathrm{a}$ & $21.1 \mathrm{~b}$ & $8.7 \mathrm{a}$ & $1.0 \mathrm{~b}$ & $25.7 \mathrm{a}$ & $19.1 \mathrm{~b}$ & $93.5 \mathrm{a}$ & $92.4 \mathrm{a}$ \\
\hline 25 & $8.0 \mathrm{~b}$ & $46.6 \mathrm{a}$ & $25.0 \mathrm{a}$ & $25.3 \mathrm{a}$ & $9.5 \mathrm{a}$ & $\mathrm{ND} b$ & $43.5 \mathrm{a}$ & $24.0 \mathrm{~b}$ & $91.0 \mathrm{~b}$ & $95.9 \mathrm{a}$ \\
\hline \multicolumn{11}{|c|}{ Depth $(2-5 \mathrm{~cm})$} \\
\hline 4 & $94.5 \mathrm{a}$ & $93.5 \mathrm{a}$ & ND & ND & ND & ND & $5.0 \mathrm{a}$ & $4.5 \mathrm{a}$ & $95.5 \mathrm{a}$ & $98.5 \mathrm{a}$ \\
\hline 11 & $57.8 \mathrm{~b}$ & $74.9 \mathrm{a}$ & $23.0 \mathrm{a}$ & $13.6 \mathrm{~b}$ & ND & ND & $16.1 \mathrm{a}$ & $10.3 \mathrm{~b}$ & 96.9 a & $98.8 \mathrm{a}$ \\
\hline 17 & $29.4 \mathrm{~b}$ & $56.5 \mathrm{a}$ & $36.5 \mathrm{a}$ & $23.8 \mathrm{~b}$ & $3.6 \mathrm{a}$ & $\mathrm{ND} b$ & $23.1 \mathrm{a}$ & $17.0 \mathrm{~b}$ & $92.6 \mathrm{~b}$ & $97.3 \mathrm{a}$ \\
\hline 25 & $12.9 \mathrm{~b}$ & $28.0 \mathrm{a}$ & $37.5 \mathrm{a}$ & $39.4 \mathrm{a}$ & $3.3 \mathrm{a}$ & $\mathrm{ND} b$ & $30.7 \mathrm{a}$ & $24.6 \mathrm{~b}$ & $84.4 \mathrm{~b}$ & $92.2 \mathrm{a}$ \\
\hline
\end{tabular}

${ }^{a}$ Means for a component at a given day followed by the same letter do not differ significantly at the 95\% confidence level comparing NT and CT tillage regimes. 
Table 3

Recovery of ${ }^{14} \mathrm{C}$ label in fluometuron and metabolites from the 5-10 and $10-25 \mathrm{~cm}$ depths of a Dundee silt loam as affected by tillage at various times after incubation ${ }^{\mathrm{a}}$

\begin{tabular}{|c|c|c|c|c|c|c|c|c|}
\hline \multirow[t]{3}{*}{ Day } & \multicolumn{8}{|c|}{$\%$ initial ${ }^{14} \mathrm{C}$ fluometuron recovered as } \\
\hline & \multicolumn{2}{|c|}{ Fluometuron } & \multicolumn{2}{|c|}{ Desmethyl fluometuron } & \multicolumn{2}{|c|}{ Non-extractable } & \multicolumn{2}{|c|}{ Total recovery } \\
\hline & $\mathrm{CT}$ & NT & $\mathrm{CT}$ & NT & CT & NT & $\mathrm{CT}$ & NT \\
\hline \multicolumn{9}{|c|}{ Depth $(5-10 \mathrm{~cm})$} \\
\hline 4 & $95.1 \mathrm{a}$ & $93.5 \mathrm{a}$ & ND & ND & $3.2 \mathrm{a}$ & $4.5 \mathrm{a}$ & $98.3 \mathrm{a}$ & $98.0 \mathrm{a}$ \\
\hline 11 & $76.9 \mathrm{~b}$ & $86.5 \mathrm{a}$ & $11.0 \mathrm{a}$ & $4.4 \mathrm{~b}$ & $8.2 \mathrm{a}$ & $6.2 \mathrm{a}$ & $94.1 \mathrm{a}$ & $97.1 \mathrm{a}$ \\
\hline 17 & $62.0 \mathrm{~b}$ & $79.6 \mathrm{a}$ & $17.4 \mathrm{a}$ & $8.4 \mathrm{~b}$ & $14.5 \mathrm{a}$ & $8.2 \mathrm{~b}$ & $93.9 \mathrm{a}$ & $96.2 \mathrm{a}$ \\
\hline 25 & $39.8 \mathrm{~b}$ & $67.4 \mathrm{a}$ & 32.9 a & $18.4 \mathrm{~b}$ & $23.2 \mathrm{a}$ & $12.9 \mathrm{~b}$ & 95.9 a & $98.7 \mathrm{a}$ \\
\hline \multicolumn{9}{|c|}{ Depth $(10-25 \mathrm{~cm})$} \\
\hline 4 & $97.0 \mathrm{a}$ & $95.6 \mathrm{a}$ & ND & ND & $2.1 \mathrm{a}$ & $2.3 \mathrm{a}$ & $99.1 \mathrm{a}$ & $97.9 \mathrm{a}$ \\
\hline 11 & $95.7 \mathrm{a}$ & $91.2 \mathrm{a}$ & $1.1 \mathrm{a}$ & $3.2 \mathrm{a}$ & $3.2 \mathrm{a}$ & $5.3 \mathrm{a}$ & $98.9 \mathrm{a}$ & $98.6 \mathrm{a}$ \\
\hline 17 & $89.2 \mathrm{a}$ & $79.3 \mathrm{~b}$ & $4.7 \mathrm{a}$ & $13.4 \mathrm{~b}$ & $5.0 \mathrm{a}$ & $6.1 \mathrm{a}$ & $98.9 \mathrm{a}$ & $98.8 \mathrm{a}$ \\
\hline 25 & $82.4 \mathrm{a}$ & $67.7 \mathrm{~b}$ & $8.8 \mathrm{a}$ & $21.6 \mathrm{~b}$ & $6.7 \mathrm{a}$ & $8.8 \mathrm{a}$ & $97.9 \mathrm{a}$ & $98.1 \mathrm{a}$ \\
\hline
\end{tabular}

${ }^{a}$ Means for a component at a given day followed by the same letter do not differ significantly at the $95 \%$ confidence level comparing NT and CT tillage regimes.

\subsection{Fluometuron sorption}

Batch equilibria studies indicated a significant interaction of tillage on fluometuron sorption in the upper three soil depths. Freundlich coefficients $\left(K_{\mathrm{f}}\right)$ were almost fourfold greater in NT 0-2 cm soil compared to the similar depth in the CT soil (Table 4). At the 5-10, and $10-25 \mathrm{~cm}$ soil depths, $K_{\mathrm{f}}$ values were about $40 \%$ higher in NT compared to CT soil. $K_{\mathrm{f}}$ values in NT soils decreased with increasing depth to $10 \mathrm{~cm}$. In CT soils, the highest $K_{\mathrm{f}}$ values were observed in the $2-5 \mathrm{~cm}$ depth, and were lowest below the $5 \mathrm{~cm}$ depths. Although organic matter was about $50 \%$ greater in the $0-2 \mathrm{~cm}$ depth of NT compared to

Table 4

Fluometuron Freundlich sorption coefficients in a Dundee silt loam as affected by tillage and soil depth ${ }^{\mathrm{a}}$

\begin{tabular}{llllll}
\hline $\begin{array}{l}\text { Soil depth } \\
(\mathrm{cm})\end{array}$ & \multicolumn{2}{l}{$K_{\mathrm{f}}\left(\mathrm{l} \mathrm{kg}^{-1}\right)$} & & & \multicolumn{2}{l}{$1 / N$ (dimensionless) } \\
\cline { 2 - 3 } \cline { 5 - 6 } & $\mathrm{NT}$ & $\mathrm{CT}$ & & $\mathrm{NT}$ & $\mathrm{CT}$ \\
\hline $0-2$ & $7.19(0.20)$ & $1.89(0.09)$ & & $0.80(0.01)$ & $0.83(0.02)$ \\
$2-5$ & $1.96(0.07)$ & $2.18(0.08)$ & & $0.78(0.01)$ & $0.80(0.01)$ \\
$5-10$ & $1.41(0.06)$ & $1.04(0.09)$ & & $0.79(0.01)$ & $0.86(0.03)$ \\
$10-25$ & $1.46(0.05)$ & $1.16(0.05)$ & & $0.78(0.01)$ & $0.82(0.01)$ \\
\hline
\end{tabular}

${ }^{\text {a }}$ Values in parenthesis are standard deviations of coefficients.
CT soil, the potential for fluometuron sorption was about fourfold higher in NT soils, suggesting both qualitative and quantitative changes in organic matter following long-term NT. The $K_{\mathrm{f}}$ values for NT in the $2-5 \mathrm{~cm}$ depths were the same as or slightly less than that in CT. The $2-5 \mathrm{~cm}$ of CT has the surface residues mixed in during tillage, whereas in NT, the OM in the $2-5 \mathrm{~cm}$ is aged organic matter from that accumulated prior to initiation of NT or the result of movement of soluble organic carbon. There was less mixing of soil below $5 \mathrm{~cm}$ for $\mathrm{CT}$ as indicated by no significant difference in organic matter values between NT and CT. Studies by Brown et al. (1994) indicated that there was no significant effect of organic matter on fluometuron degradation. However, in these studies fluometuron degradation was slower in CT soil with no cover crop compared to NT soils with a hairy vetch cover crop. The high sorption potential in the NT surface soil supports the hypothesis of low bio-availability, thus restricting degradation. Despite impeded degradation potential, high fluometuron sorption in surface NT soil may minimize leaching potential to lower soil depths. In all cases, sorption was non-linear over concentration as evidenced by an $N$ coefficient value of less than 1 . This indicated that fluometuron sorption decreased with increasing fluometuron concentration. 
Table 5

Fluometuron first-order degradation constants in NT and CT Dundee silt loam soil collected at four depths ${ }^{\mathrm{a}}$

\begin{tabular}{llllll}
\hline Depth $(\mathrm{cm})$ & \multicolumn{2}{l}{$k$ (per day) } & & \multicolumn{2}{l}{$k$ (per day) corrected for solution phase fluometuron } \\
\cline { 2 - 3 } & CT & NT & CT & NT \\
\hline $0-2$ & $0.0754(0.0184)$ & $0.0345(0.0026)$ & $0.405(0.099)$ & $0.802(0.060)$ \\
$2-5$ & $0.0608(0.0114)$ & $0.0368(0.0026)$ & $0.380(0.071)$ & $0.202(0.034)$ \\
$5-10$ & $0.0273(0.0046)$ & $0.0145(0.0009)$ & $0.091(0.0015)$ & $0.059(0.004)$ \\
$10-25$ & $0.0074(0.0008)$ & $0.0138(0.0015)$ & $0.027(0.0003)$ & $0.057(0.006)$ \\
\hline
\end{tabular}

${ }^{a}$ Values in parenthesis are standard deviations of the coefficients.

\subsection{Kinetic analysis fluometuron degradation}

Fluometuron degradation was adequately described $\left(r^{2}>0.85\right.$, data not shown) by first-order kinetics (Table 5). The degradation constants observed in 0 $5 \mathrm{~cm}$ CT surface soils $(0.060-0.075)$ in our studies are somewhat higher than those reported by others (0.010-0.037) under controlled conditions (Mueller et al., 1992; Brown et al., 1994). However, first-order constants at the 10-25 cm depths of CT and NT soils were much lower than that reported for a $15-30 \mathrm{~cm}$ depth of a Beulah silt loam (Mueller et al., 1992). When degradation constants were calculated on a basis of fluometuron concentration in solution, fluometuron degradation proceeded more rapidly in the NT 0-2 cm soil depth than other depths (Table 5), as would be expected with the greater microbial biomass and activity. Comparison of these two kinetic analyzes suggests that limited bio-availability of fluometuron due to sorption to the organic matter components may have a greater effect on fluometuron degradation than elevated microbial characteristics.

\section{Summary}

Long-term (11 years) continuous NT management resulted in a accumulation of organic matter in the upper $0-2 \mathrm{~cm}$ soil depth. Organic matter accumulation in the surface $0-2 \mathrm{~cm}$ of NT soil was accompanied by increased microbial biomass, microbial activity, and sorption of fluometuron compared to the $0-2 \mathrm{~cm}$ depth of CT soil. However, despite increased carbon substrate availability, and microbial biomass and activity, fluometuron degradation was impeded at this depth most likely due to limited bio-availability. Likewise, limited introduction of fresh labile organic matter at the lower soil depths resulted in lower microbial biomass and activity and fluometuron degradation in the $2-10 \mathrm{~cm}$ depth of NT compared to CT soils. Interactions between effects of tillage regime on both herbicide bio-availability and microbiological activity need to be considered when predicting the fate of herbicides under NT practices. These results have important implications when considering weed control, herbicide efficiency and herbicide fate under long-term NT cropping systems.

\section{References}

Brown, B.A., Hayes, R.M., Tyler, D.D., Mueller, T.C., 1994. Effect of tillage and cover crop on fluometuron adsorption and degradation under controlled conditions. Weed Sci. 42, 629634.

Brown, B.A., Hayes, R.M., Tyler, D.D., Mueller, T.C., 1996. Effect of long-term vetch (Vicia villosa) cover crop and tillage system on fluometuron dissipation from surface soil. Weed Sci. 44, 171-175.

Doran, J.W., 1980. Soil microbial and biochemical changes associated with reduced tillage. Soil Sci. Soc. Am. J. 44, 765-771.

Jorgenson, R.G., Brooks, P.C., 1990. Ninhydrin positive nitrogen measurements of microbial biomass in $0.5 \mathrm{~K}_{2} \mathrm{SO}_{4}$ soil extracts. Soil Biol. Biochem. 22, 1023-1027.

Levanon, D., Meisinger, J.J., Codling, E.E., Starr, J.L., 1994. Impact of tillage on microbial activity and the fate of pesticides in upper soil. Water, Air, Soil Pollut. 72, 179-237.

Linn, D.M., Doran, J.W., 1984. Aerobic and anaerobic microbial populations in no-tilled and plowed soils. Soil. Sci. Soc. Am. J. 48, 794-799.

Locke, M.A., 1992. Sorption-desorption kinetics of alachlor in surface soils from two soybean tillage systems. J. Environ. Qual. 21, 558-566.

Locke, M.A., Bryson, C.T., 1997. Herbicide-soil interactions in reduced-tillage and plant residue management systems. Weed Sci. 45, 307-320.

Locke, M.A., Harper, S.S., 1991. Metribuzin degradation in soil. II. Effects of tillage. Pestic. Sci. 31, 137-221. 
Locke, M.A., Zablotowicz, R.M., Gaston, L.A., 1995. Fluometuron interactions in crop-residue managed soils. In: Kingerey, W.L., Buehring, N. (Eds.), Conservation Farming: A Focus on Water Quality. MAFES Special Bulletin No. 88-7. Mississippi Agricultural Forestry Experiment Station, MS, pp. 55-58.

Locke, M.A., Gaston, L.A., Zablotowicz, R.M., 1996. Alachlor biotransformation and sorption in soil from two soybean tillage systems. J. Agric. Food Chem. 44, 1128-1134.

Locke, M.A., Gaston, L.A., Zablotowicz, R.M., 1997. Acifluorfen sorption and sorption kinetics in soil. J. Agric. Food Chem. 45, 286-293.

Locke, M.A., Zablotowicz, R.M., Bauer, P.J., Gaston, L.A., Bryson, C.T., 1999. Herbicide dissipation in cotton production systems in Mississippi and South Carolina. WSSA Abstr. 39, 45.

Mueller, T.C., Moorman, T.B., Snipes, C.E., 1992. Effect of concentration, sorption, and microbial biomass on the degradation of fluometuron in surface and subsurface soils. J. Agric. Food Chem. 40, 2517-2522.

Nelson, D.W., Sommers, L.E., 1982. Total carbon, organic carbon and organic matter. In: Page, A.L., Miller, R.H., Keeney, D.H. (Eds.), Methods of Soil Analysis, Part 2, 2nd Edition. Chemical and Microbiological Properties. Agron. Serial No. 9. American Society of Agronomy, Madison, WI, pp. 539-580.

Reddy, K.N., Zablotowicz, R.M., Locke, M.A., 1995. Chlorimuron adsorption, desorption and degradation in soils from conventional and no-tillage systems. J. Environ. Qual. 24, 760-767.

Reddy, K.N., Locke, M.A., Zablotowicz, R.M., 1997. Soil type and tillage effects on sorption of cyanaizine and degradation products. Weed Sci. 45, 727-732.
Schnürer, J., Roswall, T., 1982. Fluorescein diacetate hydrolysis as a measure of total microbial activity in soil and litter. Appl. Environ. Microbiol. 43, 1256-1261.

van Genuchten, M.T., 1981. Non-equilibrium transport parameters from miscible displacement experiments. Research Report No. 119. US Salinity Laboratory, Riverside, CA.

Wagner, S.C., Zablotowicz, R.M., Locke, M.A., Bryson, C.T., 1995. Influence of herbicide-desiccated cover crops on biological soil quality in the Mississippi Delta. In: Kingerey, W.L., Buehring, N. (Eds.), Conservation Farming: A Focus on Water Quality. MAFES Special Bulletin No. 88-7. Mississippi Agricultural Forestry Experiment Station, MS, pp. 55-58.

Wagner, S.C., Zablotowicz, R.M., Gaston, L.A., Locke, M.A., Kinsella, J., 1996. Bentazon degradation in soil: influence of tillage and history of bentazon application. J. Agric. Food Chem. 44, 1593-1598.

Wagner, S.C., Zablotowicz, R.M., 1997. Effect of organic amendments on the remediation of cyanazine and fluometuron in soil. J. Environ. Sci. Health B 34, 37-54.

Zablotowicz, R.M., Locke, M.A., Smeda, R.J., 1998. Degradation of 2,4-D and fluometuron in cover crop residues. Chemosphere $37,87-101$.

Zablotowicz, R.M., Locke, M.A., Knight, S.S., 2000. Microbiological characteristics and fluometuron concentrations of Mississippi Delta oxbow lakes in the MSEA project. In: Ballweber, J.A., (Ed.), Proceedings of the 30th Mississippi Water Resources Conference. Water Resources Research Institute, Mississippi State University, MS, pp. 38-42. 